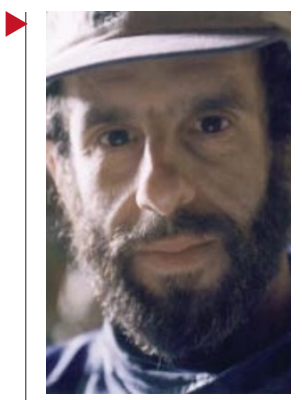

Paul Ginsparg: set to move to Cornell.

Society, produced a consensus that the operation would enjoy more secure funding and stronger intellectual support at a university than at LANL.

But for Ginsparg, the last straw was his recent salary review, which, he says, described him as "a strictly average performer by overall lab standards; with no particular computer skills contributing to lab programs; easily replaced, and moreover overpaid, according to an external market survey".

LANL officials declined to comment on Ginsparg's case, but said that some recent salary increases at the laboratory have been available only to certain combinations of programmes and individual skills.

Peter Lepage, chair of Cornell's physics department, notes wryly of the LANL assessment: "Evidently their form didn't have a box for: 'completely transformed the nature and reach of scientific information in physics and other fields.”

http://arXiv.org

\title{
Imported stem cells deepen Germany's ethical divide
}

\section{Quirin Schiermeier, Munich}

The charged debate in Germany over research on human embryonic stem (ES) cells boiled over earlier this week, with the news that at least one scientist has already imported human ES cell lines.

Wolfgang-Michael Franz, a cardiologist at the Ludwig Maximilian University of Munich, revealed on 2 July that in March he received human ES lines, ordered from the WiCell Research Institute in Madison, Wisconsin. He has not yet used the cells, but plans to seek funding from the DFG, Germany's main research granting body, to develop cardiac muscle from the cell lines.

Although German law bans the isolation of human ES cells from 'spare' embryos, their import is not prohibited. But with public feelings running high, the import of cells is intensely controversial. Last week, when it emerged that Stefan Rose-John, a biochemist at the University of Kiel, planned to import stem cells, he was criticized in the media.

Meanwhile, police are assessing the safety of Oliver Brüstle of the University of Bonn, who was the first to apply to the DFG to work on human ES cells. Brüstle received death threats after the Frankfurter Allgemeine Zeitung published details of a patent application that included his private address.

The science ministry seems to have been caught off-guard by the latest revelations. "I call on all researchers planning to use human stem cells to wait for a vote of the national ethics council," says science minister Edelgard Bulmahn. The council is expected to deliver its opinion on whether research should go ahead in the autumn.

The German parliament will vote on a moratorium on the import of stem cells on 5 July. But it is unlikely to find a majority, as the ruling Social Democrat-Green coalition has agreed for now not to impose additional restrictions on biomedical research.

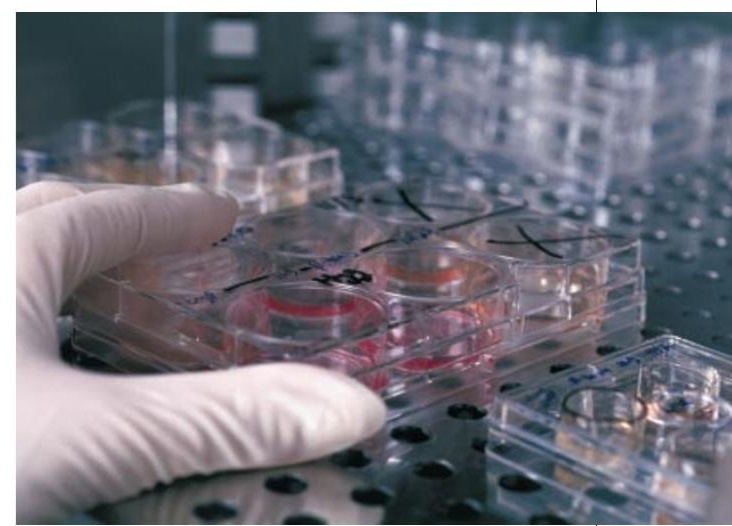

Eye of the storm: WiCell's human embryonic stem cells have been imported into Germany.

\section{Quota offered as solution to gender imbalance}

\section{Katja Henssel, Munich}

Germany is looking at a controversial answer to the perennial problem of gender inequality in the workplace. A law being considered by the German parliament would introduce a quota system for women in governmentfunded jobs, including those in science.

Currently, only about $5 \%$ of top positions

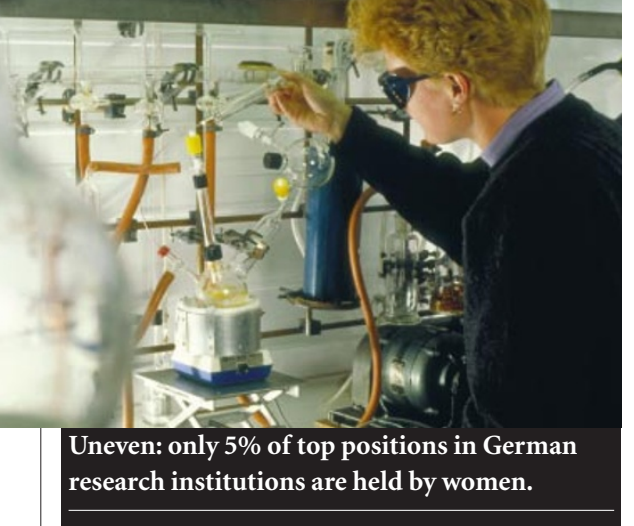

at public research institutes and universities in Germany are held by women, compared with nearly $14 \%$ in France and $11 \%$ in Italy.

The government wants to change that fast. "By 2005, we want at least $20 \%$ of full professorships and other leading scientific positions to be filled with women," says Helga Ebeling, head of the federal science ministry's division for women in education and research.

The legislation, which would cover universities as well as government-funded research institutions, was drafted by the government in the spring and is scheduled to be considered by the parliament in the autumn. It already has the support of the ruling Social Democrat-Green coalition.

German research organizations and prominent scientists say that they welcome action on gender discrimination. But many doubt that a quota system is the best approach to fixing the problem.

"It would certainly cause a quick injection of women into the science system,"
Christiane Nüsslein-Volhard, director of the Max Planck Institute for Developmental Biology in Tübingen, told a meeting on women in science last month at the European Molecular Biology Organization in Heidelberg. "But the idea that you owe your job to a quota has an unpleasant taste," she said. "It devalues your skills."

Klaus Landfried, president of the Association of Universities and Other Higher Education Institutions in Germany, says that a quota system would undermine the authority of women in top scientific positions. "It is the least clever way to improve opportunities for women," he says.

Supporters of a quota system include Sybille Krummacher, a scientist at the national research centre in Jülich (FZJ), who helped to set up Germany's first women-only tenure-track programme. "The programme has encouraged many women to apply," says Krummacher, "and they are not employed just because they are female, but because they are highly qualified." 